\title{
Planting Date and Genotype Effects on Tepary Bean Productivity
}

\author{
Harbans L. Bhardwaj', Muddappa Rangappa, and Anwar A. Hamama \\ Agricultural Research Station, Virginia State University, P.O. Box 9061, \\ Petersburg, VA 23806
}

Additional index words. seed yield, seed weight, harvest index, crop diversification, drought tolerance

\begin{abstract}
Our objective was to evaluate production potential of eight tepary bean (Phaseolus acutifolius A. Gray) genotypes and three planting dates. Significant variation $(P<0.05)$ existed among eight genotypes and three planting dates in 1997 and 1998. The genotype $\times$ planting date interaction was nonsignificant $(P>0.05)$ for seed yield and harvest index. Seed yields of eight genotypes, when averaged over three planting dates and 2 years, varied from 1618 to 1988 with a mean of $1816 \mathrm{~kg}^{\circ} \mathrm{ha}^{-1}$, indicating that tepary bean is adapted to Virginia's agro-climatic conditions. The harvest index (ratio between seed and total plant weight, expressed as percentage) ranged from $38 \%$ to $47 \%$. Seed weight varied from 12.6 to $18.8 \mathrm{~g}$ with a mean of $14.5 \mathrm{~g}$. Genotypes with tan-colored seeds had significantly larger seed than those with black or white seeds. Planting dates significantly affected seed yield, seed weight, and harvest index. The highest seed yield $\left(2239 \mathrm{~kg} \cdot \mathrm{ha}^{-1}\right)$ and harvest index were obtained from the late May plantings.
\end{abstract}

The need for increased production of food and/or feed grains to keep pace with everincreasing human population and preservation of natural resources are emphasized by the estimated addition of $\approx 75$ million people per year until 2020 (International Food Policy Research Institute, 1999). The use of inorganic fertilizers, especially nitrogen, has created a dilemma for modern agriculture: on one hand, their use has been linked to environmental pollution, while on the other hand they have contributed to yield increases (Drinkwater et al., 1998). Underutilized legumes, such as tepary bean (Phaseolus acutifolius A. Gray), can serve as alternative sources of food and/or feed grains, maximize water use efficiency because of their high level of drought resistance (Thomas et al., 1983), reduce water pollution resulting from the use of inorganic nitrogen fertilizers, and diversify cropping systems.

Tepary bean, a native to northwestern Mexico and southwestern United States, received special honor for flavor and reliability of yields under rain-fed conditions at the 1912 International Dry Bean Congress. Yet its promise was never realized due to the development of irrigation, made possible by diverting rivers and pumping groundwater (Nabhan, 1983). A 1983 symposium, titled "The Desert Tepary as a Food Resource," concluded that planting and consumption of tepary bean is undergoing

Received for publication 7 Aug. 2001. Accepted for publication 4Dec. 2001. We thank Dermot P. Coyne, Univ. of Nebraska, Lincoln, for providing the seed of tepary bean genotypes used in these studies. Contribution of Virginia State Univ., Agricultural Research Station, Journal Article Series No. 224. The use of any trade names or vendors does not imply approval to the exclusion of other products or vendors that may also be suitable.

${ }^{1}$ To whom reprint requests should be addressed. Phone: 804-524-6723; fax: 804-524-5950; e-mail: hbhardwj@vsu.edu a revival due to increasing costs of pumping water, demand for natural foods, and concerns for conserving the genetic diversity of plant resources (Nabhan, 1983). However, tepary beans have not received much research interest even though 163 cultivated and 156 wild tepary bean accessions are stored in germplasm repositories throughout the world (Debouck, 1991). Miklas et al. (1994) suggested that there is a need to evaluate tepary beans for production potential in specific environments.

The cultivated tepary bean, similar to dry bean (Phaseolus vulgaris L.), is a short lifecycle annual desert legume indigenous to northwestern Mexico and the southwestern United States (Nabhan and Felger, 1978). Tepary beans are known to be resistant to many diseases, such as common bacterial blight caused by Xanthomonas campestris pv. phaseoli (Smith) Dye, and bean golden mosaic virus (Bigeminivirus: Geminiviridae), and have been used as donor parents to improve dry bean (Miklas and Santiago, 1996; Singh and Munoz, 1999). They are tolerant to heat and drought stress and produce nutritious, high-protein seed that is suitable for human consumption (Miklas et al., 1994; Thomas et al., 1983). In addition, they may have special value in Virginia and other southeastern states where wheat (Triticum aestivum L.) farmers traditionally have not had a crop to plant following wheat harvest in summer, and to harvest prior to planting of the next wheat crop during the fall. Some wheat farmers plant soybean [Glycine max (L.) Merr.] as a doublecrop system, but the productivity of doublecropped soybean is extremely low and variable.

The present studies were prompted by a continuing need for diversification, increasing water shortages for irrigation, and a need for a short-duration crop to fit winter wheat rotation. Our goal was to ascertain the feasibility of tepary bean production. Specifically, we wanted to determine effects of planting dates on the productivity of different tepary bean genotypes.

\section{Materials and Methods}

Eight tepary bean genotypes (Neb-T-3, Neb-T-4, Neb-T-5, Neb-T-8, Neb-T-9, NebT-11, Neb-T-14, and Neb-T-15), supplied by Dermot P. Coyne, Univ. of Nebraska, Lincoln, were used in these studies. At this time, an adequate amount of seed was only available for these genotypes. These genotypes had black, tan, or white seeds (Table 1). These genotypes were planted on three dates in 1997 (29 May, 19 June, and 10 July) and 1998 (30 May, 22 June, and 10 July) at Randolph Farm of Virginia State Univ., located in Ettrick, Va. $\left(37^{\circ} 15^{\prime} \mathrm{N}\right.$ and $\left.077^{\circ} 30.8^{\prime} \mathrm{W}\right)$. Each experiment consisted of three replicates per planting date (randomized complete-block design). Limited quantities of seed necessitated the use of single rows in 1997 when we used a breeding line of soybean, similar in height and size to tepary bean, to plant guard rows with each tepary bean row to avoid border effects. However, during 1998, all plots consisted of three rows. The rows were $6 \mathrm{~m}$ long with betweenrow spacing of $75 \mathrm{~cm}$. About 200 seeds, without any seed treatment, were planted in each row with a cone-type planter at a depth of $\approx 2.5$ $\mathrm{cm}$. These plots received no fertilizer or irrigation applications. The soil for these plots was kept fallow during the previous fall season. The soil type was Abel sandy loam (Fine Loamy mixed thermic Aquatic Hapridult). The weeds in these plots were controlled manually. All plots received one application of permethrin ( $60 \mathrm{~g} \cdot \mathrm{h}^{-1}$ a.i. of Ambush) and one application of lambda-cyhalothrin $\left(20 \mathrm{~g} \cdot \mathrm{h}^{-1}\right.$ a.i. of Karate) insecticides. At maturity in early October, all plots were end-trimmed to avoid border effects. We did not record data on plant size and maturity, but harvesting was conducted when all plots had matured. All plots were harvested (only the middle row in 1998) manually by cutting at ground level, and dried for $\approx 4$ weeks in an open building. Before threshing with a stationary thresher, data on total plant weight, including seeds and plant material, were recorded. Data were recorded on seed yield $\left(\mathrm{kg} \cdot \mathrm{ha}^{-1}\right)$ and weight of 100 seeds (g) at $\approx 5 \%$ moisture. Harvest index was calculated as a ratio between seed weight and total plant weight and expressed as percentages.

All data were analyzed by procedures in version 6.11 of SAS (SAS, 1996). Duncan's multiple range test was used for mean separation with a significance level of $5 \%$.

\section{Results and Discussion}

Significant variation existed for seed yield, seed weight, and harvest index among eight genotypes (Table 2). Planting date and year effects were significant $(P>0.05)$ for seed yield and harvest index. The interactions between years, planting dates, and genotypes were nonsignificant $(P>0.05)$ for seed yield and harvest index. The years $\times$ planting dates, 
Table 1. Seed color, seed yield, seed weight, and harvest index for eight tepary bean genotypes averaged over three planting dates and 2 years in Virginia.

\begin{tabular}{lllcc}
\hline \hline Genotype & $\begin{array}{c}\text { Seed } \\
\text { color }\end{array}$ & $\begin{array}{c}\text { Seed } \\
\text { yield } \\
\left(\mathrm{kg} \cdot \mathrm{ha}^{-1}\right)\end{array}$ & $\begin{array}{c}\text { Seed } \\
\mathrm{wt} \\
(\mathrm{g} / 100 \mathrm{seed})\end{array}$ & $\begin{array}{c}\text { Harvest } \\
\text { index } \\
(\%)\end{array}$ \\
\hline Neb-T-4 & Black & $1988 \mathrm{a}^{*}$ & $14.2 \mathrm{c}^{*}$ & $45.8 \mathrm{a}-\mathrm{c}^{*}$ \\
Neb-T-5 & Tan & $1928 \mathrm{ab}$ & $14.9 \mathrm{~b}$ & $45.9 \mathrm{a}-\mathrm{c}$ \\
Neb-T-11 & White & $1920 \mathrm{ab}$ & $13.8 \mathrm{c}$ & $46.1 \mathrm{ab}$ \\
Neb-T-15 & Black & $1862 \mathrm{a}-\mathrm{c}$ & $14.9 \mathrm{~b}$ & $47.1 \mathrm{a}$ \\
Neb-T-9 & White & $1833 \mathrm{a}-\mathrm{c}$ & $14.0 \mathrm{c}$ & $44.0 \mathrm{bc}$ \\
Neb-T-8 & Black & $1719 \mathrm{a}-\mathrm{c}$ & $12.6 \mathrm{~d}$ & $43.2 \mathrm{c}$ \\
Neb-T-3 & Tan & $1658 \mathrm{bc}$ & $18.8 \mathrm{a}$ & $38.1 \mathrm{~d}$ \\
Neb-T-14 & Tan & $1618 \mathrm{c}$ & $15.3 \mathrm{~b}$ & $45.9 \mathrm{a}-\mathrm{c}$ \\
\hline
\end{tabular}

${ }^{2}$ Ratio between seed weight and total aboveground plant weight (including seed weight), expressed as percentage.

"Values followed by similar letters are not different $(P>0.05)$.

years $\times$ genotypes, and planting dates $\times$ genotypes interactions were significant $(P>0.05)$ for seed weight. However, the interactions involving genotypes were of extremely small magnitude (Table 2) as compared to the effects of genotypes. Therefore, the means for planting dates averaged over eight genotypes and 2 years, and means for eight genotypes averaged over three planting dates and 2 years were compared. The values of coefficients of determination $\left(R^{2}\right)$ and variation for the three traits (Table 2) indicated that experimental design, conduct of experiments, and analysis were satisfactory.

The seed yield of eight genotypes, averaged over planting dates and years, varied from 1618 to 1988 with a mean of 1816 $\mathrm{kg} \cdot \mathrm{ha}^{-1}$ (Table 1). Based on average yields, the three highest yielding genotypes (Neb-T-4, Neb-T-5, and Neb-T-11) had black, tan, or white seeds. Miklas et al. (1994) indicated that tepary bean seeds are suitable for human consumption. The lack of differences among black, tan, or white-seeded genotypes for seed yield indicates that, depending upon consumer preference or other considerations, either of these genotypes could be used for commercial production.

Delayed planting resulted in reduced seed yield (Table 3 ). The highest mean seed yield of $2239 \mathrm{~kg} \cdot \mathrm{ha}^{-1}$ was obtained when plantings were made around May 29. However, this planting date in a winter wheat rotation may not be feasible because wheat usually is harvested in mid-June in Virginia. Mid-June planting resulted in $\approx 15 \%$ reduction ( 2239 vs. 1899 $\mathrm{kg} \cdot \mathrm{ha}^{-1}$ ) in yield. Early July plantings caused a further $31 \%$ yield $\left(1899 \mathrm{vs} .1310 \mathrm{~kg} \cdot \mathrm{ha}^{-1}\right)$. The seed yields in our studies compared favorably with yields of 769 to $1640 \mathrm{~kg} \cdot \mathrm{ha}^{-1}$ for 11 tepary beans evaluated across six tropical environments in Puerto Rico and Honduras (Miklas et al., 1994). Moreover, it is worth noting that the seed yield from even the July planting (1310 $\mathrm{kg} \cdot \mathrm{ha}^{-1}$ ) compared favorably with double-crop soybean yields of $\approx 1000 \mathrm{~kg} \cdot \mathrm{ha}^{-1}$. Thus, most Virginia farmers could easily adopt the tepary beans for double-cropping.

The seed weight varied from 12.6 to $18.8 \mathrm{~g}$ per 100 seeds (Table 1). Delay in planting from late-May to mid-June or mid-June to mid-July did not affect seed weight (Table 3). A combined look at the seed yield and seed weight indicates that a delay in planting from

Table 2. Partial analysis of variance for seed yield, 100-seed weight, and harvest index for eight tepary bean genotypes evaluated at three planting dates in Virginia in 1997 and 1998.

\begin{tabular}{lrccc}
\hline \hline Source & df & Seed yield & 100-Seed wt & Harvest index $^{2}$ \\
\hline Years (Y) & 1 & $13359711^{*}$ & 11.2 & $0.530^{* * *}$ \\
Planting dates (PD) & 2 & $10605862^{* *}$ & 12.1 & $0.020^{*}$ \\
Genotypes (G) & 7 & $332445^{*}$ & $59.7^{* *}$ & $0.015^{* *}$ \\
Y $\times$ PD & 2 & 577703 & $51.8^{* * *}$ & 0.002 \\
Y $\times$ G & 7 & 265444 & $3.5^{* *}$ & 0.001 \\
$\mathrm{PD} \times \mathrm{G}$ & 14 & 138589 & $1.2^{*}$ & 0.002 \\
$\mathrm{Y} \times \mathrm{PD} \times \mathrm{G}$ & 14 & 170125 & 0.8 & 0.002 \\
Error & 84 & 136422 & 0.6 & 0.001 \\
\hline$R^{2}$ & --- & 80.1 & 93.5 & 87.0 \\
$\mathrm{CV}$ & --- & 20.3 & 5.0 & 8.3
\end{tabular}

$\overline{{ }^{2} \text { Ratio between seed weight and total aboveground plant weight (including seed }}$ weight), expressed as percentage.

*** Significant at $P=0.05$ and 0.01 , respectively. Mean squares due to years were tested against years $\times$ rep as error mean squares; mean squares due to PD and years $\times \mathrm{PD}$ were tested against years $\times$ rep $\times \mathrm{PD}$ as error mean squares.

mid-June to early July may reduce the number of total seeds produced, but the seed weight will be unaffected.

Harvest index values close to $40 \%$ are usually indicative of physiological adaptation of a new crop under the changed environmental conditions. Bhardwaj and Bhagsari (1989, 1990, and 1991) reported a harvest index of $\approx 50 \%$ for soybean, a well-established crop in Virginia. The harvest index of eight tepary bean genotypes varied from $38 \%$ to $47 \%$ (Table $1)$, indicating that the tepary bean is well adapted to Virginia's agro-climatic conditions. Delayed planting from late May to mid-June caused a reduction of $6 \%$ in the harvest index. However, a further delay to early July did not affect harvest index. As observed in many other field crops, including soybean, a significant $(P<0.01)$ positive relationship existed between seed yield and harvest index $(r=$ 0.63 ) of tepary bean in our studies. A significant negative relationship existed between harvest index and seed weight $(-0.28, P<$ 0.01 ) in tepary beans grown in Virginia.

Our results demonstrate that tepary bean can be successfully produced in Virginia. The seed yield was reduced by delayed planting, indicating that the ideal time for planting tepary bean in Virginia is late May. Nonetheless, the tepary bean seed yield from plantings done in mid-June compared favorably with doublecropped soybeans. Thus, use of tepary bean in rotation with winter wheat in Virginia is possible.

\section{Literature Cited}

Bhardwaj, H.L. and A.S. Bhagsari. 1989. Harvest index, yield, and physiological characteristics of soybean as related to seed size. Soybean Genet. Nwsl. 16:133-136.

Bhardwaj, H.L. and A.S. Bhagsari. 1990. Harvest index and related characteristics of small and large seeded soybean genotypes. Soybean Genet. Nwsl. 17:109-113.

Bhardwaj, H.L. and A.S. Bhagsari. 1991. Soybean harvest index as related to yield, plant architecture, and economic value. Soybean Genet. Nwsl. 18:314-316.

Debouck, D.G. 1991. Diversity in Phaseolus species in relation to the common bean, p. 25-52. In S.P. Singh (ed.). Common bean improvement in
Table 3. Mean seed yield, seed weight, and harvest index for three planting dates averaged over eight tepary bean genotypes and 2 years in Virginia.

\begin{tabular}{lccc}
\hline \hline $\begin{array}{l}\text { Planting } \\
\text { date }\end{array}$ & $\begin{array}{c}\text { Seed } \\
\text { yield } \\
\left(\mathrm{kg} \cdot \mathrm{ha}^{-1}\right)\end{array}$ & $\begin{array}{c}\text { Seed wt } \\
(\mathrm{g} / 100 \mathrm{seed})\end{array}$ & $\begin{array}{c}\text { Harvest } \\
\text { index }^{z} \\
(\%)\end{array}$ \\
\hline Late May $^{\mathrm{y}}$ & $2239 \mathrm{a}^{*}$ & $14.9 \mathrm{a}$ & $46.7 \mathrm{a}^{*}$ \\
Mid-June $^{\mathrm{x}}$ & $1899 \mathrm{~b}$ & $14.3 \mathrm{a}$ & $44.0 \mathrm{ab}$ \\
Mid-July $^{\mathrm{w}}$ & $1310 \mathrm{c}$ & $15.3 \mathrm{a}$ & $42.8 \mathrm{~b}$
\end{tabular}

${ }^{2}$ Ratio between seed weight and total aboveground plant weight (including seed weight), expressed as percentage.

צ29 May 1997 and 30 May 1998

×19 June1997 and 22 June 1998.

w10 July 1997 and 10 July 1998.

"Values followed by similar letters are not different $(P>0.05)$.

the twenty-first century. Kluwer, Dordrecht, Netherlands.

Drinkwater, L.E., P. Wagoner, and M. Sarrantonio. 1998. Legume-based cropping systems have reduced carbon and nitrogen losses. Nature 396:262-265

International Food Policy Research Institute (IFPRI). 1999. Feeding the world in the next millennium: Farmers must produce 40 percent more grain. Washington, D.C. (http://www.cgiar.org/ifpri/ 102799.htm).

Miklas, P.N. and J. Santiago. 1996. Reaction of select tepary bean to bean golden mosaic virus. HortScience 31:430-432.

Miklas, P.N., J.C. Rosas, J.S. Beaver, L. Telek, and G.P. Freytag. 1994. Field performance of select tepary bean germplasm in the tropics. Crop Sci. 34:1639-1644.

Nabhan, G.P. 1983. The desert tepary as a food source. In: Frank S. Crosswhite (ed.). Desert plants. Vol. 5, No. 1. Published by Univ. of Arizona for the Boyce Thompson Southwestern Arboretum, Superior, Ariz.

Nabhan, G.P. and R.S. Felger. 1978. Teparies in southwestern North America. Econ. Bot. 32:219.

SAS. 1996. SAS system for windows. SAS Inst., Cary, N.C.

Singh, S.P. and C.G. Munoz. 1999. Resistance to common bacterial blight among Phaseolus species and common bean improvement. Crop Sci 39:80-89.

Thomas, C.V., R.M. Manshardt, and J.G. Waines. 1983. Teparies as a source of useful traits for improving common beans. In: Frank S. Crosswhite (ed.). Desert Plants 5(1):43-48. 